\section{Methodological adjustments to the tetrazolium test in coriander seeds}

\author{
Raimunda Nonata Oliveira da Silva ${ }^{1}(\mathbb{D})$, Gizele Ingrid Gadotti ${ }^{1}{ }^{(1)}$, Ireni Leitzke \\ Carvalho $^{1}$ (D), Ivan Ricardo Carvalho ${ }^{2}$ (D), Jerffeson Araujo Cavalcante ${ }^{1}$ (D), \\ Joseano Graciliano da Silva ${ }^{1 *}$
}

\begin{abstract}
The reduction in the time to perform the tetrazolium test is critical in decision making at pre and post-harvest of seeds. Thus, the objective of this study was to investigate different concentrations of the tetrazolium salt solution, temperatures, and staining times, to reduce the time for assessing the viability of coriander seeds by the tetrazolium test. The study was divided into two experiments conducted independently but sequentially. The seeds were evaluated for water content, germination, and viability in both experiments by the tetrazolium test. A completely randomized design was used, with four replications. For the tetrazolium test, the seeds were preconditioned by direct immersion in water for sixteen hours at $20^{\circ} \mathrm{C}$. In experiment I, the seeds were exposed to different concentrations of the tetrazolium salt solution $(0.25 ; 0.5 ; 0.75$; and $1.0 \%)$. In experiment II, different combinations of temperatures $\left(35 ; 40\right.$; and $45^{\circ} \mathrm{C}$ ) and staining times (three, four, five, and six hours) were tested. Based on the findings, it was concluded that the best staining pattern of coriander seeds for performing the tetrazolium test is achieved by using the concentration of $0.5 \%$ tetrazolium salt solution for five hours at $40{ }^{\circ} \mathrm{C}$.
\end{abstract}

Index terms: Coriandrum sativum L., viability, quick test.

RESUMO: A redução no tempo de execução do teste de tetrazólio é fundamental na tomada de decisão em pré e pós-colheita de sementes. Dessa maneira, o objetivo desta pesquisa foi estudar diferentes concentrações da solução do sal de tetrazólio, temperaturas e tempos de coloração, visando reduzir o tempo de avaliação da viabilidade de sementes de coentro pelo teste de tetrazólio. $O$ estudo foi dividido em dois experimentos conduzidos de maneira independente, porém, sequencial. Em ambos os experimentos, as sementes foram avaliadas quanto ao teor de água, germinação e viabilidade pelo teste de tetrazólio. Utilizou-se delineamento experimental inteiramente casualizado, com quatro repetições. Para o teste de tetrazólio, as sementes foram pré-condicionadas por imersão direta em água, por dezesseis horas a $20{ }^{\circ} \mathrm{C}$. No experimento I, as sementes foram expostas a diferentes concentrações da solução do sal de tetrazólio $(0,25 ; 0,5 ; 0,75$; e 1,0\%). No experimento II, foram testadas diferentes combinações de temperaturas $\left(35 ; 40\right.$; e $45^{\circ} \mathrm{C}$ ) e tempos de coloração (três; quatro; cinco; e seis horas). Com base nos resultados obtidos, concluiu-se que a melhor coloração de sementes de coentro para a realização do teste de tetrazólio é obtida utilizando a concentração da solução do sal de tetrazólio de $0,5 \%$ por cinco horas a $40{ }^{\circ} \mathrm{C}$.

Termos para indexação: Coriandrum sativum L., viabilidade, teste rápido.
Journal of Seed Science, v.43, e202143026, 2021

http://dx.doi.org/10.1590/ 2317-1545v43251969

\footnotetext{
*Corresponding author E-mail:joseano_agronomo@ outlook.com
}

Received: 5/7/2021. Accepted: 7/23/2021.

\footnotetext{
${ }^{1}$ Faculdade de Agronomia Eliseu Maciel, Universidade Federal de Pelotas, 96050-500 - Pelotas, RS, Brasil.
}

${ }^{2}$ Universidade Regional do Noroeste do Estado do Rio Grande do Sul, 98700-000 - ljuí, RS, Brasil. 


\section{INTRODUCTION}

The use of seeds with high physiological potential is an essential requirement to obtain a homogeneous field with well-established plants. Also, it is one of the factors that help to ensure successful agricultural production (Paiva et al., 2016; França-Neto and Krzyzanowski, 2019). Faced with this requirement, the seed production sector has sought to make quick and efficient decisions (Rodrigues et al., 2015) based on quick response tests to determine seed viability and vigor.

Seed viability can be determined by germination and tetrazolium tests (Brasil, 2009a; ISTA, 2017; AOSA/SCST, 2014). In most commercial species, the germination test can take between one and four weeks. However, for coriander seeds, this test has limitations, especially concerning execution time, which is relatively long; a total of 21 days are needed to achieve the results (Brasil, 2009a; ISTA, 2012). Sometimes, this test can be underestimated due to contamination from pathogens that cause difficulty reading the test data.

On the other hand, the tetrazolium test is a biochemical test that determines the percentage of viable seeds based on the activity of dehydrogenase enzymes, regardless of either the dormancy level of these seeds or their fungal contamination (Elias et al., 2012; ISTA, 2017; AOSA/SCST, 2014). In this sense, the tetrazolium test is an essential complementary alternative to the germination test to assess seeds that present dormancy or slow or uneven germination (Brasil, 2009a; Marcos-Filho, 2015).

Although there is a methodology for coriander crops described in the "Working Sheets on Tetrazolium Testing" (ISTA, 2003), there is no record of using this method as a routine practice in internal quality control programs in Brazil. In the procedure proposed by ISTA (2003), viability results are achieved in 48 hours, owing to the long period of preconditioning ( 24 hours) and exposure ( +24 hours) for coloring the seeds in the tetrazolium solution.

Also, a 1.0\% tetrazolium salt solution concentration is recommended, and two sections (transverse and longitudinal) have to be performed to test and assess seed viability. All these factors make it challenging to apply this methodology, as a convenience and faster analyses are increasingly desired.

In a study on methodological adjustment with carrot seeds, Lima et al. (2018) managed to reduce the test execution time from 42 to four hours and the concentration of the salt solution from 1.0 to $0.1 \%$. Similarly, Lima et al. (2010), working with cucumber seeds, achieved a decrease from 42 to three hours and the concentration of the tetrazolium salt solution from 1.0 to $0.075 \%$.

Because a long period is required to conduct the germination test, and fungi may interfere when testing seeds of this species, the tetrazolium test needs to be used, in addition to the germination test, to assess viability. However, it is noteworthy that the methodology of the tetrazolium test in coriander seeds can still be improved. Thus, the objective of the present study was to investigate different concentrations of the tetrazolium salt solution, temperatures, and exposure times, aiming to reduce the time for assessing the viability of coriander seeds when using the tetrazolium test.

\section{MATERIAL AND METHODS}

The study was conducted at the Seed Analysis Laboratory, Faculdade de Agronomia Eliseu Maciel, Universidade Federal de Pelotas, RS, Brazil. It used commercial lots of coriander cv. Verdão seeds from the southern region of Rio Grande do Sul, Brazil.

The study was divided into two experiments conducted independently but sequentially. Both experiments were carried out in a completely randomized design, with four replications for each treatment. The treatments in experiment I consisted of using four concentrations of the tetrazolium salt solution $(0.25 ; 0.5 ; 0.75 ;$ and $1.0 \%)$. Experiment II used the general average of the four lots, in a $3 \times 4$ factorial arrangement, with three temperatures $\left(35 ; 40\right.$; and $\left.45^{\circ} \mathrm{C}\right)$ and four times of exposure to the tetrazolium salt solution (three; four; five; and six hours) for seed coloring.

The two experiments used coriander seeds, represented by six and four lots, respectively. The germination test was carried out with and without chemical treatment of the seeds in experiment I and without chemical treatment 
in experiment II. In both experiments, 100 seeds were used in each replication. The methodologies used for both experiments are described below:

Water content: carried out in an oven at a temperature of $105 \pm 3{ }^{\circ} \mathrm{C}$ for 24 hours, using two subsamples of $4.5 \mathrm{~g}$ of seeds per lot, according to Brasil (2009a). The results were expressed as average water content percentage.

Germination test: the seeds were sown on blotting paper sheets moistened with distilled water in an amount equivalent to 2.5 times the dry paperweight, placed in Gerbox ${ }^{\circledR}$ plastic boxes, and taken to a room with a constant temperature of $20^{\circ} \mathrm{C}$. The final germination assessment was carried out 21 days after sowing, considering standard seedling percentage (Brasil, 2009a).

In experiment I, the seeds underwent chemical treatment to avoid pathogen interference. The seeds were treated with a fungicide with active principles Metalaxyl-m+ Fludioxonil, at a rate of $200 \mathrm{~mL} .100 \mathrm{~kg}^{-1}$ of seeds. The seed treatment was applied according to the methodology proposed by Nunes (2005). In experiment II, the germination test was performed with seeds disinfected with 1.0\% sodium hypochlorite for three minutes (Brasil, 2009a; Brasil, 2009b).

Tetrazolium test: seeds were initially preconditioned by immersion in water for sixteen hours at a temperature of $20^{\circ} \mathrm{C}$ (Figure 1A). After the preconditioning period, the seeds were sectioned longitudinally (Figure 1B) while keeping half of each of the two seeds present in the fruit (Figure 1C). Next, these seeds were placed in plastic trays containing fifty cells (holes) to prevent the seeds from mixing, leading to separating the two parts of the fruit.

Five seeds were placed in each cell. Then, with the aid of a micropipette (Figure 1D), $1.5 \mathrm{~mL}$ of the tetrazolium salt solution (2,3,5-triphenyl tetrazolium chloride) was added over six hours, at a temperature of $40^{\circ} \mathrm{C}$. Among the concentrations used in experiment $\mathrm{I}$, we chose to use the best concentration of the tetrazolium salt $(0.5 \%)$ in experiment II.

After the coloring period, the seeds were considered as viable in the following conditions: a) presence of pink/ bright red colored tissues and absence of non-colored areas (in the endosperm and the embryo), with firm tissues in the two halves of the fruit (Figure $2 \mathrm{~A}$ ); $\mathrm{b}$ ) at least one of the fruit seeds had bright red color throughout its length (Figures 2B, 2C and 2D).

The seeds were considered as non-viable in the following conditions: a) absence of color in the embryo, even if the endosperm had some color (Figure 2E); b) seeds with a very faint pink color, with little activity in seed tissues (Figures $2 \mathrm{~F}$ and $2 \mathrm{G})$; c) seeds with intense carmine red color on both halves and/or lack of color in more than $1 / 3$ in the critical region of the endosperm (near the embryo) and the embryo (Figure 2H); d) absence of color throughout the two seeds of the fruit (Figure 2I).

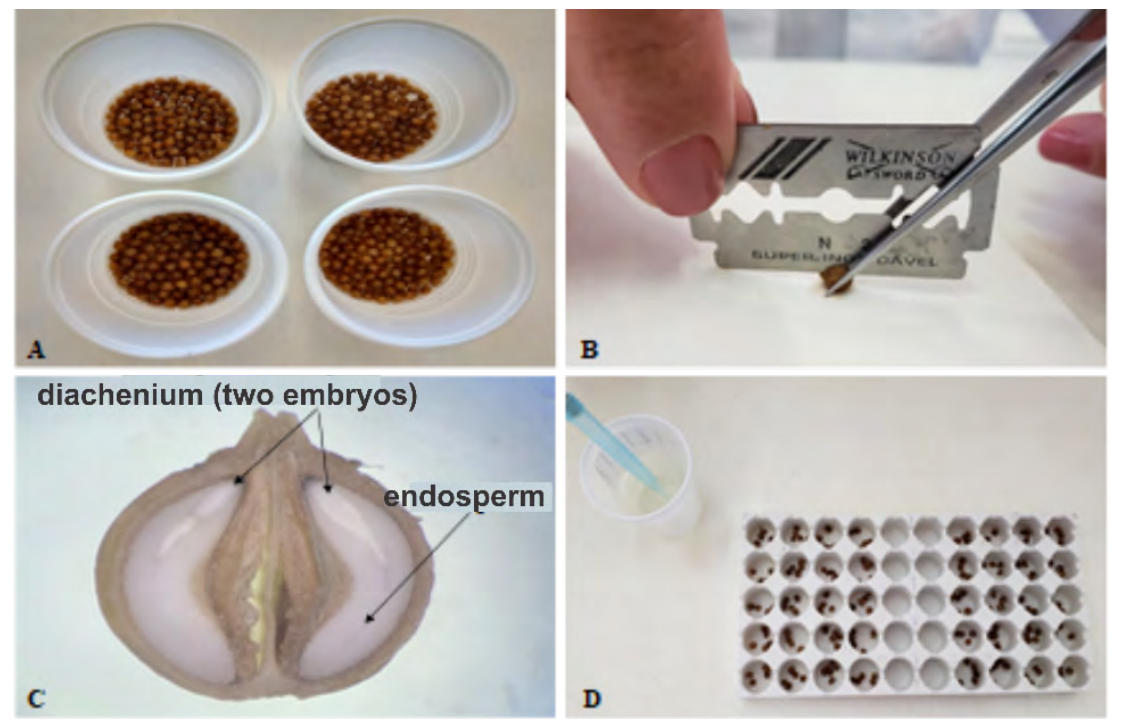

Figure 1. Preparation of coriander seeds in the different stages of conduction of the tetrazolium test: pre-wetting with water immersion $(A)$; longitudinal sectioning of the fruit $(B)$; detail of seed structure showing diachenium (two embryos) and the endosperm (C); and seeds in the tetrazolium salt solution (D). 


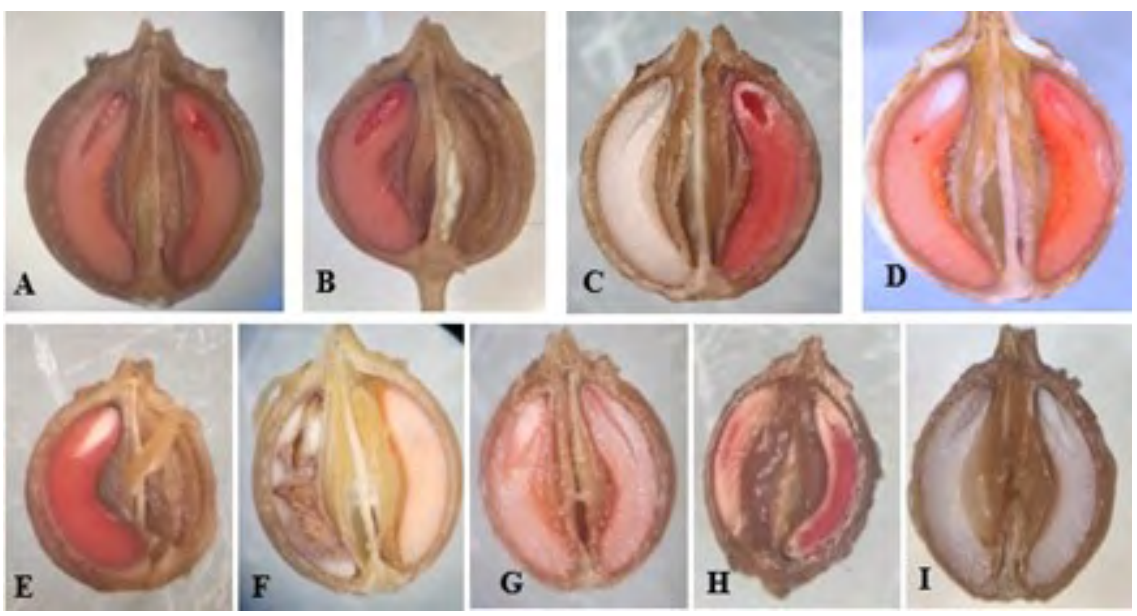

Figure 2. Classes to determine the viability of coriander seeds by the tetrazolium test: viable (A, $B, C, D)$; and non-viable $(E, F, G, H$, and $I)$.

Data from both experiments were analyzed for normality and homoscedasticity of variance. Then, they underwent analysis of variance $(p<0.05)$ and, when data were significant, polynomial regressions were applied to the data from the experiment I; linear models with increasing effect were applied to compare the behavior between the results for the seeds with and without treatment in the germination and tetrazolium tests. In experiment II, Tukey's test at 5\% was applied to the temperature data, while polynomial regressions were applied to the exposure time data. Finally, data on viability from experiment II were compared with those found in the germination test by analyzing the efficiency of the tetrazolium test, using the average values of the lots, according to Carvalho et al. (2017) (Eq.1):

Eficiência TZn = [1 - (|G-TZn|)/G] 100 (Eq. 1), where: $G$ = percentage of normal seedlings obtained in the germination test; $T Z n=$ percentage of viable seeds found in the tetrazolium tests.

\section{RESULTS AND DISCUSSION}

\section{Experiment I - Viability of coriander seeds based on different concentrations of the tetrazolium salt solution}

Table 1 shows the results of the initial characterization of the six coriander seed lots. The average water contents ranged from 7.6 to $9.8 \%$, with a maximum variation of 2.2 percentage points (pp). These values are similar to those found in studies with coriander seeds to assess physiological quality (Nascimento et al., 2006; Torres et al., 2015; Radke et al., 2016). After the preconditioning period (sixteen hours at $20^{\circ} \mathrm{C}$ ), the seeds presented an average water content of $53.5 \%$ (Table 1 ).

According to Novembre et al. (2006), the percentage of water absorbed by the seeds for tissue hydration can be used as a reference parameter to standardize the conditions for conducting the tetrazolium test. In this sense, seed water content after preconditioning must reach a minimum value for proper activation of the enzymatic system (Souza et al., 2009). This study's results indicate that the seeds' water content found after sixteen hours of preconditioning was sufficient to activate the metabolism of coriander seeds, as indicated by tissue coloring (Table 2 and Figure 1).

Germination percentages of coriander seeds without chemical treatment with fungicide were above $90 \%$ for lots 1 to 5 had germination. However, only lot 6 showed a germination rate below $90 \%$, significantly different from that of the other lots (Table 1). In this type of research, lots with contrasting levels of quality are desirable since the tetrazolium test methodology must be efficient in identifying the physiological quality of a lot, regardless of whether it is high, medium, or low (Carvalho et al., 2019). 
Table 1. Water content before and after preconditioning and germination of six lots of coriander seeds with and without chemical fungicide treatment.

\begin{tabular}{ccccc}
\hline \multirow{2}{*}{ Lots } & \multicolumn{2}{c}{ Water content (\%) } & \multicolumn{2}{c}{ Germination (\%) } \\
\cline { 2 - 5 } & Initial & Post-imbibition & Untreated & Treated** $^{*}$ \\
\hline 1 & 9.1 & 55.2 & $94 \mathrm{a}$ & $97 \mathrm{a}$ \\
2 & 9.6 & 54.4 & $97 \mathrm{a}$ & $98 \mathrm{a}$ \\
3 & 9.7 & 54.0 & $94 \mathrm{a}$ & $95 \mathrm{ab}$ \\
4 & 9.8 & 50.3 & $92 \mathrm{a}$ & $94 \mathrm{ab}$ \\
5 & 9.7 & 52.7 & $94 \mathrm{a}$ & $97 \mathrm{a}$ \\
6 & 7.6 & 54.6 & $81 \mathrm{~b}$ & $90 \mathrm{~b}$ \\
\hline Mean & 9.3 & 53.5 & 92 & 95 \\
C.V.\% & - & - & 2.59 & 2.65 \\
\hline
\end{tabular}

*Means followed by the same lowercase letter in the column do not differ statistically by Tukey's test at 5\% probability. C.V.: coefficient of variation.

**Coriander seeds treated with Metalaxyl-m+ Fludioxonil.
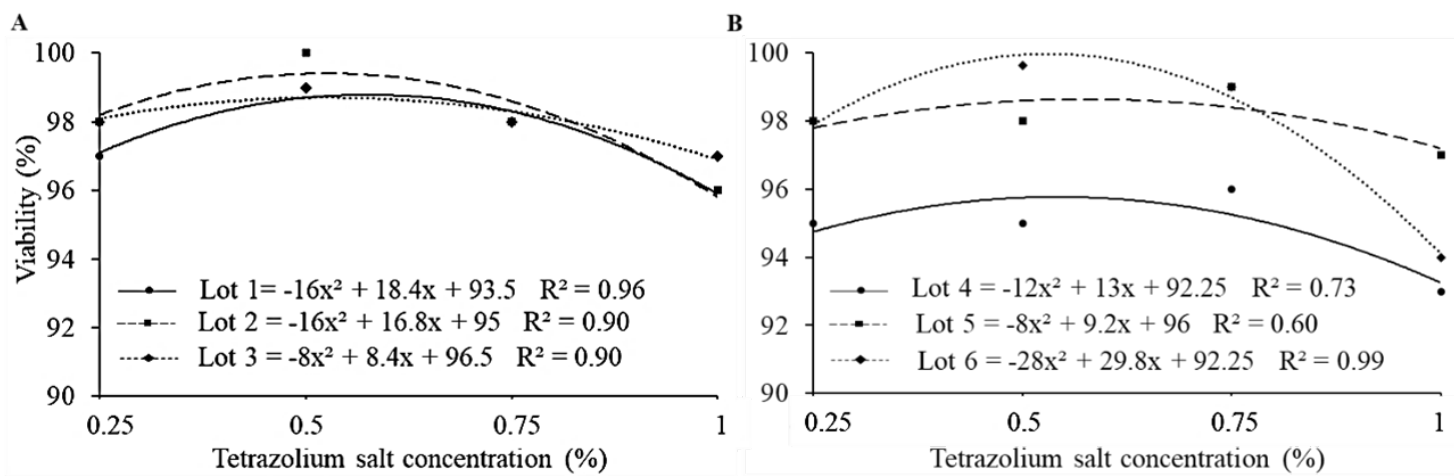

Figure 3. Maximum technical efficiency of coriander seed viability by the tetrazolium test conducted with different concentrations of the tetrazolium salt solution.

When evaluating the germination test results of coriander seeds under chemical treatment with fungicide (Table 1), it was found that lots 1 to 5 had higher germination percentages than lot 6 . However, all lots had a germination rate equal to or greater than $90 \%$.

The treatment of seeds with fungicide possibly minimized the effect of the fungi that had infected the seeds, especially in lot 6 , whose germination was nine percentage points ( $p p$ ) higher than germination with treated seeds (90\%). On the other hand, this lot without fungicide treatment had average germination of $81 \%$. Notably, the treatment of seeds with fungicide aims to protect the seeds and seedlings from possible attacks by fungi present in the soil and by fungi that are already present in the seeds, which can interfere with the results of the germination test (Goulart, 2018).

As found in this study, treating seeds with a fungicide before the germination test can inhibit the proliferation of fungi that may affect the performance of the seeds during the test.

After analyzing the results for maximum technical efficiency, using different concentrations of the tetrazolium salt solution, based on a significant model, a quadratic trend was found for all coriander seed lots (Figures $3 \mathrm{~A}$ and $3 \mathrm{~B}$ ). Lots 1,2 , and 3 increases in viability as the concentration of the tetrazolium salt solution increased, with maximum efficiency point at concentrations of $0.58,0.52$, and $0.54 \%$, respectively for each lot, with a subsequent decrease in viability up to a concentration of $1.0 \%$ (Figure $3 \mathrm{~A}$ ). 


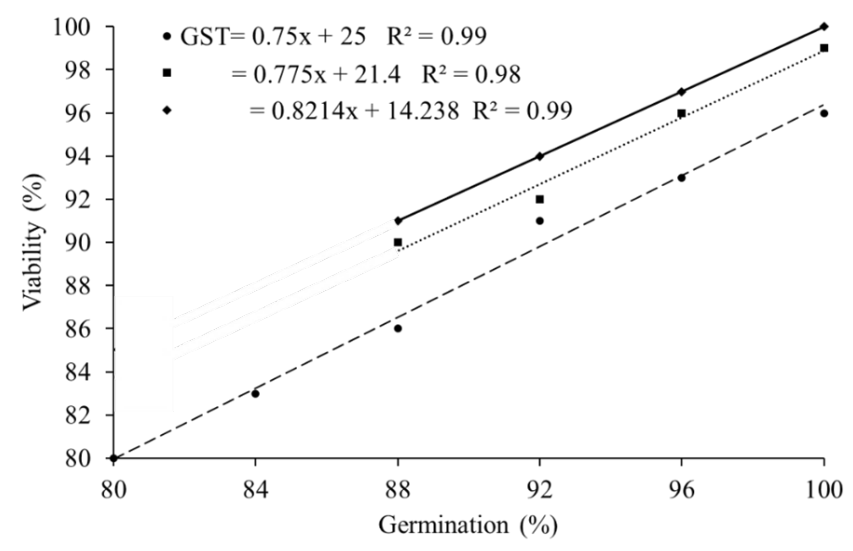

Figure 4. Linear models with increasing effect on the viability of coriander seeds by the tetrazolium test, using the concentration of $0.5 \%$ of the tetrazolium salt solution and the germination test without seed treatment with fungicide (GST) and with treatment (GCT).

For lots 4, 5, and 6, the tetrazolium salt solution concentrations that provided the highest viability values were $0.54,0.59$, and $0.54 \%$, respectively (Figure $3 \mathrm{~B}$ ). An average concentration of $0.55 \%$ was found among all coriander seed lots. Thus, the $0.5 \%$ concentration would be the most suitable for performing the tetrazolium test in coriander seeds in the laboratory routine.

In the "Working Sheets on Tetrazolium Testing" (ISTA, 2003), a concentration of $1.0 \%$ has been suggested for coriander seeds; however, in this study, the use of more dilute concentrations, e.g., $0.5 \%$, has already provided satisfactory results to determine the maximum viability potential of coriander seeds.

Several authors (Lima et al., 2010; Flores et al., 2015; Nery et al., 2015 and Vera et al., 2019) reported difficulty interpreting the test when the seeds were exposed to a concentration of $1.0 \%$, as they presented a very intense red color. This fact posed challenges to the interpretation of the test, especially when associated with prolonged times of exposure and combination with temperatures above $40^{\circ} \mathrm{C}$.

When linear models with increasing effect were applied (Figure 4), the germination of seeds treated with fungicides presented results whose trend was similar to that of the results for the viability of seeds evaluated with the tetrazolium test - compared to the germination values of seeds without treatment. However, the germination values were lower than those of viability achieved in the tetrazolium test, possibly owing to the interference of fungi in the germination test, which explains the equidistant mean between the results.

In this sense, Santos et al. (1992), studying the tetrazolium test in cotton seeds, found higher viability values than those in the germination test for seeds that did not undergo chemical treatment with a fungicide. However, according to these same authors, a more expressive correlation was found when the seeds were treated with a fungicide.

The tetrazolium test is not affected by the interference of fungi that may be infecting the seeds, one of the possible reasons why there were significant differences between the viability values determined by the tetrazolium test and the germination test (Brasil, 2009a).

Thus, coriander seeds' germination and viability values will only show the same tendency when the seeds are free of pathogens or treated with fungicides, owing to an inhibition of fungi that infect the seeds - one of the main interferences in the germination test of coriander seeds in the laboratory. Thus, the tetrazolium test for coriander seeds is as accurate as of the germination test when estimating the potential viability of a given lot.

Experiment II - Viability of coriander seeds by the tetrazolium test based on temperature and exposure time in the tetrazolium salt solution

According to the data shown in Table 2, the average initial water content of the seed lots was 9.7\%. However, after sixteen hours of preconditioning, the seeds had an average water content of $52.7 \%$ (Table 2 ). This value was similar to 
those found in experiment I of this study.

The assessment of the germination results showed that all lots had germination above $90 \%$, with an average of $96 \%$. Only lot 1 showed germination below 95\%, a significantly different result from the other lots (Table 2).

Based on the results of experiment II, the use of tetrazolium salt at a concentration of $0.5 \%$, in this experiment, caused seed coloring at a temperature of $45{ }^{\circ} \mathrm{C}$ with values higher than those found at a temperature of $35{ }^{\circ} \mathrm{C}$ at the exposure times of three, four and five hours and above the temperature of $40{ }^{\circ} \mathrm{C}$, when the seeds were exposed for three and four hours (Table 3).

Comparing the results between the temperatures of 35 and $40{ }^{\circ} \mathrm{C}$ was found that the seeds under $40{ }^{\circ} \mathrm{C}$ had higher viability values than those found at the temperature of $35^{\circ} \mathrm{C}$ at the exposure times of three, four, and five hours (Table 3). Notably, the combination of three and four hours of exposure at temperatures 35 and $40^{\circ} \mathrm{C}$ provided lower viability values than those found in the germination test (Tables 2 and 3). This result shows that coriander seeds should remain in the tetrazolium solution for at least six hours when using a temperature of $35^{\circ} \mathrm{C}$ and five hours at a temperature of $40^{\circ} \mathrm{C}$ to achieve satisfactory levels of color.

On the other hand, for a temperature of $45^{\circ} \mathrm{C}$, the minimum period of three hours of exposure was enough to achieve results consistent with the germination test. In short, in this experiment, it was found that the higher the temperature, the shorter the time needed for the coriander seeds to remain in contact with the tetrazolium solution.

There was a different behavior for a 6-hour exposure of coriander seeds in the tetrazolium salt solution (Table 3) compared to the other exposure times. However, the treatment with six hours of exposure provided similar viability values at all temperatures, with values equal to or greater than $96 \%$.

Table 2. Water content before and after preconditioning and germination of four lots of coriander seeds.

\begin{tabular}{|c|c|c|c|}
\hline \multirow{2}{*}{ Lots } & \multicolumn{2}{|c|}{ Water content (\%) } & \multirow{2}{*}{ Germination (\%) } \\
\hline & Initial & Post-imbibition & \\
\hline 1 & 9.8 & 50.3 & $92 b^{*}$ \\
\hline 2 & 9.7 & 52.2 & $97 a$ \\
\hline 3 & 9.7 & 54.0 & $96 a$ \\
\hline 4 & 9.6 & 54.4 & $97 a$ \\
\hline Mean & 9.7 & 52.7 & 96 \\
\hline C.V.\% & - & - & 1.9 \\
\hline
\end{tabular}

*Means followed by the same lowercase letter in the column do not differ statistically by Tukey's test at 5\% probability. C.V.: coefficient of variation.

Table 3. Viability of coriander seeds under different temperatures and exposure times in the tetrazolium salt solution.

\begin{tabular}{cccc}
\hline & \multicolumn{3}{c}{ Viability (\%) } \\
\cline { 2 - 4 } $\begin{array}{c}\text { Exposure time } \\
\text { (hours) }\end{array}$ & 35 & Temperatures $\left({ }^{\circ} \mathrm{C}\right)$ & 45 \\
\cline { 2 - 4 } & $43 \mathrm{c}^{*}$ & 40 & $94 \mathrm{a}$ \\
4 & $66 \mathrm{c}$ & $69 \mathrm{~b}$ & $96 \mathrm{a}$ \\
5 & $86 \mathrm{~b}$ & $85 \mathrm{~b}$ & $96 \mathrm{a}$ \\
6 & $98 \mathrm{a}$ & $93 \mathrm{a}$ & $97 \mathrm{a}$ \\
\hline C.V.\% & & $96 \mathrm{a}$ & \\
\hline
\end{tabular}

*Means followed by the same lowercase letters in the column do not differ statistically by Tukey's test at $5 \%$ probability. C.V.: coefficient of variation. 
For viability based on different exposure times in the tetrazolium salt solution, for seeds from lots 1, 2, and 4 under a temperature of $35^{\circ} \mathrm{C}$, viability increased linearly as the time of salt exposure was increased (Figures 5A, 5B and 5D). For lot 3 , there was a quadratic trend at $35^{\circ} \mathrm{C}$, with a maximum efficiency point at five hours and 54 minutes (Figure $5 \mathrm{C}$ ).

For the temperature of $40{ }^{\circ} \mathrm{C}$, there was a quadratic behavior for lots 1 and 2 , with maximum viability at the exposure times of five hours and forty-two minutes and five hours and thirty minutes, respectively (Figures 5A and 5B). Both lots 3 and 4 showed an increasing linear trend (Figures $5 \mathrm{~B}$ and $5 \mathrm{C}$ ).

For seeds under a temperature of $45^{\circ} \mathrm{C}$ for different exposure periods, regardless of the coriander seed lots used, there was no significance for any polynomial model tested. For this temperature, the average viability value between the lots was $96 \%$ (Figure 5 ).

ISTA (2003) suggests 24 hours of exposure at a temperature of $30^{\circ} \mathrm{C}$ for coloring coriander seeds. However, based on this study, six hours of exposure to the tetrazolium solution, regardless of the temperature used $\left(35,40\right.$, and $\left.45^{\circ} \mathrm{C}\right)$, were sufficient to achieve satisfactory seed viability results, providing significant gains in test execution time.

In a study on methodological adjustment with carrot seeds (Daucus carota), Lima et al. (2018) found that the exposure time in the tetrazolium salt solution can be reduced from 24 to two hours. Also importantly, a long period of exposure of seeds to the solution can cause the development of a very intense red color, posing challenges to the evaluation and interpretation of the test (Barros et al., 2005).

Based on the mean methodological efficiency data of the tetrazolium test compared to the germination test (Table 4), it was found that efficiency was less for a temperature of $35^{\circ} \mathrm{C}$ in combination with three hours of exposure than $50 \%$. The efficiency values increased as the exposure time was prolonged for this temperature, achieving $97 \%$ efficiency with six hours of exposure. For $40{ }^{\circ} \mathrm{C}$, efficiency was above $95 \%$ after five hours of exposure; for a temperature of $45{ }^{\circ} \mathrm{C}$ with three hours of exposure, efficiency was higher than $95 \%$. Carvalho et al. (2017) found $97 \%$ efficiency of the tetrazolium test compared to the germination test for rice crops. These values are similar to those found in this study.
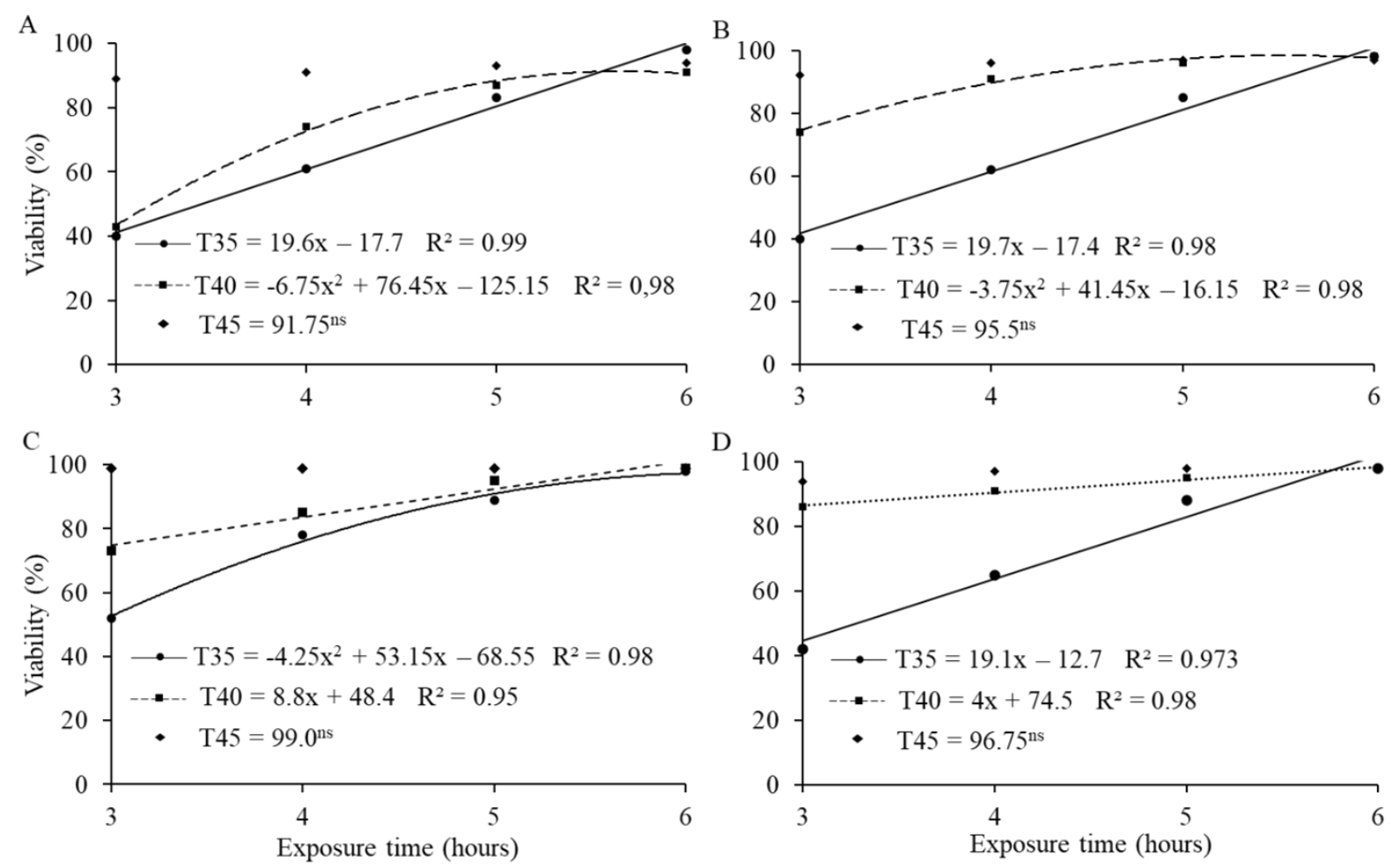

Figure 5. Viability of seeds from four coriander lots (A: lot 1, B: lot 2, C: lot 3, and D: lot 4) under different temperatures and exposure times in the tetrazolium salt solution. 
Table 4. Efficiency of the tetrazolium test considering germination and viability by the tetrazolium test based on temperature and exposure time in coriander seeds.

\begin{tabular}{ccccc}
\hline Temperature/Time $(\mathrm{h})$ & $35 / 3 \mathrm{~h}$ & $35 / 4 \mathrm{~h}$ & TZ 35/5h & $35 / 6 \mathrm{~h}$ \\
TZn* & 45.00 & 69.00 & 90.00 & 97.00 \\
\hline Temperature/Time (h) & $40 / 3 \mathrm{~h}$ & $40 / 4 \mathrm{~h}$ & TZ 40/5h & $40 / 6 \mathrm{~h}$ \\
TZn & 72.00 & 89.00 & 96.00 & 98.00 \\
\hline Temperature/Time (h) & $45 / 3 \mathrm{~h}$ & $45 / 4 \mathrm{~h}$ & $\mathrm{TZ} \mathrm{45/5h}$ & $45 / 6 \mathrm{~h}$ \\
TZn & 96.00 & 97.00 & 98.00 & 98.00 \\
\hline
\end{tabular}

$\mathrm{TZn}^{*}=$ percentage of viable seeds found in the tetrazolium tests.

\section{CONCLUSIONS}

The best coloring of coriander seeds for the tetrazolium test is achieved by using a $0.5 \%$ concentration of the tetrazolium salt solution for five hours at $40^{\circ} \mathrm{C}$.

\section{ACKNOWLEDGMENTS}

This study was conducted with the support of the Coordenação de Aperfeiçoamento de Pessoal de Nível Superior (CAPES) - funding code 001 and Conselho Nacional de Desenvolvimento Cientifico e Tecnológico (CNPq). The authors would like to thank the Post-Graduate Program in Seed Science and Technology, Faculdade de Agronomia Eliseu Maciel, Universidade Federal de Pelotas.

\section{REFERENCES}

AOSA/SCST. Association of Official Seed Analysts and Society of Commercial Seed Technologists. Rules for testing seeds, v.1. Washington, DC, 2014.

BARROS, D.I.; DIAS, D.C.F.S.; BHERING, M.C. Uso do teste de tetrazólio para avaliação da qualidade de sementes de abobrinha. Revista Brasileira de Sementes, v.27, n.2, p.165-171, 2005. https://www.scielo.br/scielo.php?script=sci_abstract\&pid=S0101$31222005000200024 \& \operatorname{lng}=e n \& n r m=i s o \&$ tlng=pt

BRASIL. Ministério da Agricultura, Pecuária e Abastecimento. Manual de análise sanitária de sementes. Ministério da Agricultura, Pecuária e Abastecimento. Secretaria de Defesa Agropecuária. Brasília: MAPA/ACS, 2009a. 202p. https://www.gov.br/agricultura/ pt-br/assuntos/insumos-agropecuarios/insumos-agricolas/sementes-e-mudas/publicacoes-sementes-e-mudas/manual-deanalise-sanitaria-de-sementes/view

BRASIL. Ministério da Agricultura, Pecuária e Abastecimento. Regras para análise de sementes. Ministério da Agricultura, Pecuária e Abastecimento. Secretaria de Defesa Agropecuária. Brasília: MAPA/ACS, 2009b. 399p. http:// https://www.gov.br/agricultura/ pt-br/assuntos/insumos-agropecuarios/arquivos-publicacoes-insumos/2946_regras_analise_sementes.pdf

CARVALHO, I.L.; MENEGHELLO, G.E.; TUNES, L.V.M.; JÁCOME, C.J.; SOARES, V.N. Methodological adjustments to the tetrazolium test in rice seeds. Journal of Seed Science, v.39, n.1, p.41-49, 2017. https://www.scielo.br/pdf/jss/v39n1/2317-1545-jss-39-01-00041.pdf

CARVALHO, I.L.; MENEGHELLO, G.E.; TUNES, L.V.M.; JÁCOME, C.J.; SOARES, V.N. Preparo da semente de arroz para execução do teste de tetrazólio. Colloquium Agrariae, v.15, p.51-63, 2019. https://revistas.unoeste.br/index.php/ca/article/view/2276/2664

ELIAS, S.G.; COPELAND, L.O.; McDONALD, M.B.; BAALBAKI, R.Z. Seed testing: principles and practices, $1^{\text {st }}$ ed. Michigan, 2012. 364p.

FLORES, M.F.; GRZYBOWSKI, C.R.S.; PAZOLINI, K.; POSSENTI, J.C.; PANOBIANCO, M. Criteria for implementation of a tetrazolium test in canola seeds. Journal of Seed Science, v.37, n.4, p.222-227, 2015. https://www.scielo.br/scielo.php?pid=S2317$15372015000400222 \&$ script $=$ sci_abstract\&tlng=pt 
FRANÇA-NETO, J.B.; KRZYZANOWSKI, F.C. Tetrazolium: an important test for physiological seed quality evaluation. Journal of Seed Science, v.41, n.3, p.359-366, 2019. https://www.scielo.br/scielo.php?script=sci_abstract\&pid=S231715372019000300359\&/ng=en\&nrm=iso

GOULART, A.C.P. Fungos em sementes de soja: detecção, importância e controle. Embrapa Agropecuária Oeste, 2018. 71p. https:// ainfo.cnptia.embrapa.br/digital/bitstream/item/184748/1/LIVRO-DOENCAS-FINAL.pdf

ISTA. International Seed Testing Association. In: ISTA working sheets on tetrazolium testing. Bassersdorf: ISTA, v.1, 2003. 171p.

ISTA. International Seed Testing Association. International rules for seed testing. Bassersdorf, Switzterland, 2017. 296p.

ISTA. International Seed Testing Association. International rules for seed testing, chapter 5: germination test. Bassesrdorf: ISTA, 2012. p.1-74.

LIMA, L.B.; PINTO, T.L.; NOVEMBRE, D.L.C. Avaliação da viabilidade e do vigor de sementes de pepino pelo teste de tetrazólio. Revista Brasileira de Sementes, v.32, n.1, p.60-68, 2010. https://www.scielo.br/scielo.php?pid=S0101-31222010000100007\&script=sci_ abstract\&tlng=pt

LIMA, C.B.; BOAVENTURA, A.C.; VILLELA, T.T. Comparação de metodologias do teste de tetrazólio para estimativa do potencial germinativo de sementes de cenoura. Horticultura Brasileira, v.36, n.2, p.240-245, 2018. http://editor.horticulturabrasileira.com. br/index.php/HB/article/view/1109

MARCOS-FILHO, J. Fisiologia de sementes de plantas cultivadas, $2^{\text {nd }}$ ed. Londrina, PR: ABRATES, 2015. 660p.

NASCIMENTO, W.M.; PEREIRA, R.S.; FREITAS, R.A.; BLUMER, L.; MUNIZ, M.F.B. Colheita e armazenamento de sementes de coentro. Pesquisa Agropecuária Brasileira, v.41, n.12, p.1793-1801, 2006. https://www.scielo.br/scielo.php?script=sci_arttext\&pid=S0100204X2006001200015

NERY, M.C.; NERY, F.C.; PIRES, R.M.O. Tetrazolium test to evaluate the viability of oil radish seeds. Bioscience Journal, v.31, n.3, p.663671, 2015. https://www.researchgate.net/publication/276424988_Tetrazolium_test_to_evaluate_the_viability_of_oil_radish_seeds

NOVEMBRE, A.D.L.C.; CHAMMA, H.M.C.P.; GOMES, R.B.R. Viabilidade das sementes de braquiária pelo teste de tetrazólio. Revista Brasileira de Sementes, v.28, n.2, p.147-151, 2006. https://www.scielo.br/scielo.php?pid=S010131222006000200020\&script=sci_arttext

NUNES, J.C. Tratamento de semente: qualidade e fatores que podem afetar a sua performance em laboratório, $1^{\text {st }}$ ed. Cidade, $2005.16 p$.

PAIVA, C.T.C.; SILVA, J.B.; DAPONT, E.C.; ALVES, C.Z.; CARVALHO, M.A.C. Qualidade fisiológica e sanitária de sementes comerciais de alface e repolho. Revista de Ciências Agroambientais, v.14, n.1, p.53-59, 2016. https://periodicos.unemat.br/index.php/rcaa/ article/view/1410/1388

RADKE, A.K.; REIS, B.B.; GEWEHRI, E.G.; ALMEIDA, A.S.; TUNES, L.M.; VILLELA, F.A. Alternativas metodológicas do teste de envelhecimento acelerado em sementes de coentro. Ciência Rural, v.46, n.1, p.1-5, 2016. https://www.scielo.br/pdf/ cr/2015nahead/1678-4596-cr-0103_8478cr20140188.pdf

RODRIGUES, A.P.M.S.; MENDONÇA-JÚNIOR, A.F.; TORRES, S.B.; NOGUEIRA, N.W.; FREITAS, R.M.O. Teste de tetrazólio para avaliação da qualidade fisiológica de sementes de Vigna unguiculata (L.) Walp. Revista Ciência Agronômica, v.46, n.3, p.638-644, 2015. https://www.scielo.br/scielo.php?pid=S180666902015000300638\&script=sci_arttext

SANTOS, V.L.M.; BANCI, C.A.; CALIL, A.C.; MENDOZA, R.M.; SILVA, R.F.; SANTOS, C.M. Utilização do teste de tetrazólio na avaliação da viabilidade e do vigor de sementes de algodão (Gossypium hirsutum L.), como um teste complementar ao teste de germinação. Revista Brasileira de Sementes, v.14, n.2, p.155-159, 1992. https://www.abrates.org.br/journal-of-seed-science/artigo/utilizaodo-teste-de-tetrazlio-na-avaliao-da-germinao-e-do-vigor-de-sementes-de-algodo-igossypium-hirsutum-il-como-um-testecomplementar-ao-teste-padro-de-germinao

SOUZA, C.R.; OHLSON, O.C.; PANOBIANCO, M. Avaliação da viabilidade de sementes de aveia preta pelo teste de tetrazólio. Revista Brasileira de Sementes, v.31, n.3, p.57-62, 2009. https://www.scielo.br/pdf/rbs/v31n3/a06v31n3.pdf

TORRES, S.B.; PAIVA, E.P.; ALMEIDA, J.P.N.; BENEDITO, C.P.; CARVALHO, S.M.C. Teste de condutividade elétrica na avaliação da qualidade fisiológica de sementes de coentro. Revista Ciência Agronômica, v.46, n.3, p.622-629, 2015. https://www.scielo.br/pdf/ rca/v46n3/0045-6888-rca-46-03-062

VERA, M.J.G.; AUMONDE, T.Z.; MENEGHELLO, G.E.; MARTINS, A.B.N.; AQUINO, Y.L.; PENA, P. Protocolo de análisis de viabilidad de semillas de chía mediante test de tetrazolio. Revista Mexicana de Ciencias Agrícolas, v.10 n.7, p.1481-1489, 2019. https://www. researchgate.net/publication/337091579_Protocolo_de_analisis_de_viabilidad_de_semillas_de_chia_mediante_test_de_tetrazolio use, distribution, and reproduction in any medium, provided the original work is properly cited. 